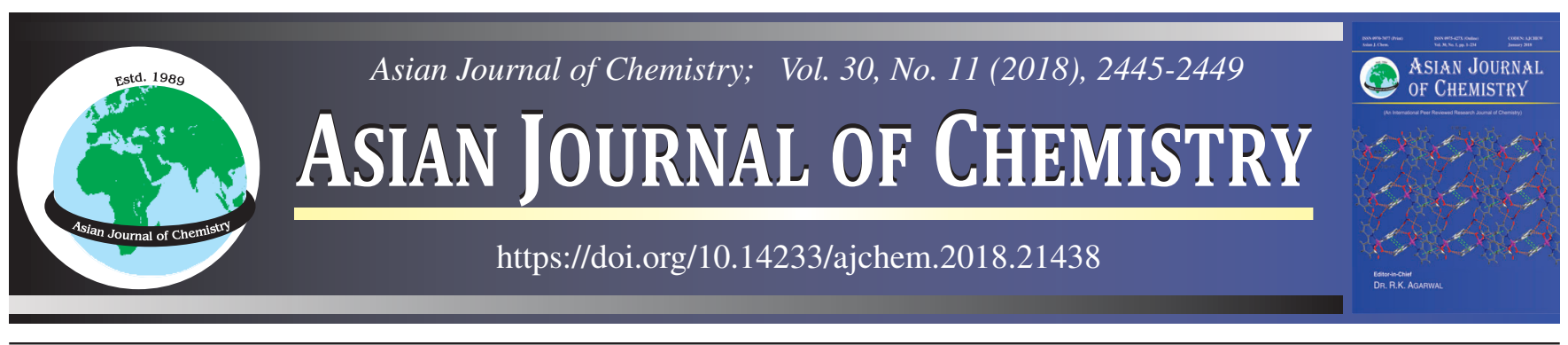

\title{
Synthesis and Characterization of Transition Metal(II) Schiff Bases Complexes Derived from 2,5-Dihalosalicylaldehyde and 4-Methyl-3-thiosemicarbazide
}

\begin{abstract}
Jai Devi", Manju Yadav and Som Sharma
Department of Chemistry, Guru Jambheshwar University of Science and Technology, Hisar-125 001, India

*Corresponding author: E-mail: jaya.gju@gmail.com

Received: 11 May 2018;

Accepted: 13 June 2018;

Published online: 27 September 2018;

AJC-19092

The metal complexes of cobalt(II), nickel(II) copper(II) and zinc(II) with Schiff bases $\left[\mathrm{HL}^{1-2}\right]$ derived from 2,5-dichlorosalicylaldehyde/ 2,5-dibromosalicylaldehyde and 4-methyl-3-thiosemicarbazide were synthesized. The structure of all the compounds have been evaluated on the basis of elemental analysis, molar conductance measurements and spectroscopic studies like FT-IR, UV-visible, NMR, ESR and mass. The Schiff base ligands existed as NOS donor coordinating to metal ion through azomethine nitrogen, sulphur of thiosemicarbazide and oxygen of deprotonated phenolic group forming complexes of the type $\left[\mathrm{M}\left(\mathrm{L}^{1-2}\right)_{2}\right]$ in 1:2 molar ratio. The spectroscopic data and physical measurement techniques suggested octahedral geometry around metal centres.

Keywords: Dibromosalicylaldehyde, Spectroscopic studies, Thiosemicarbazide, Octahedral.

ᄂ - - - - - - - - - - - - - - - - - - - - - - - - - - - - - - -
\end{abstract}

\section{INTRODUCTION}

Schiff-base ligands are versatile compounds synthesized by condensation between carbonyl compounds and primary amines. Schiff-base ligands can coordinate with different transition metal ions [1-3] and stabilize in various oxidation states. Schiff-base complexes show excellent catalytic activity [4] and exhibit broad range of biological activity [5,6]. Schiffbase complexes containing $\mathrm{Co}(\mathrm{II}), \mathrm{Ni}$ (II), $\mathrm{Cu}$ (II) and $\mathrm{Zn}$ (II) have been studied for enzymatic reactions [7], thermal analysis [8], magnetic properties $[9,10]$ and used in coordination chemistry of transition metal ions [11].

Thiosemicarbazide based Schiff bases have been widely studied since 1950 due to their tendency to bind with metal centers [12] and also due to the fact that these molecules and their complexes have been used as therapeutics and imaging agents [13]. Also, literature shows that the transition metal complexes of nitrogen-sulfur chelating agents, mainly those formed from thiosemicarbazide show variety of medicinal properties such as anticancer, antibacterial, antiviral, antitumour, antifungal, antimalarial etc. [14-18]. Thiosemicarbazides has also been used due to their variable applications in industry and analytical chemistry [19]. The molecules containing a chromophore based on the thiosemicabazide moiety has imported in increasing the light fastness [20]. With this view, we are reporting here the synthesis and characterization of $\mathrm{Co}(\mathrm{II}), \mathrm{Ni}$ (II), $\mathrm{Cu}$ (II) and $\mathrm{Zn}$ (II) complexes of Schiff base derived from 4-methyl-3-thiosemicarbazide and dihalosalicyaldehydes.

\section{EXPERIMENTAL}

All chemicals were of analytical reagent grade having high purity, purchased from Sigma Aldrich and solvents methanol, ethyl acetate, chloroform, DMSO, DMF and diethyl ether [21]. Spectrograde solvents were used for spectral and conductance measurements. The CHN elemental analysis was performed using a Perkin-Elmer CHN 2400 elemental analyzer. Molar conductance measurements of compounds with concentration $10^{-3} \mathrm{~mol} \mathrm{~L}^{-1}$ in DMSO were carried out using a Jenway 4010 conductivity meter. ${ }^{1} \mathrm{H}$ NMR spectra were measured using a Bruker $400 \mathrm{MHz}$ spectrometer with DMSO as solvent; chemical shifts are given in parts per million ( $\mathrm{ppm}$ ) relative to tetramethylsilane. Electron impact mass spectra were recorded on a Jeol, JMS, DX-303 mass spectrometer. IR spectra (4000-400 $\mathrm{cm}^{-1}$ ) were recorded as KBr pellets on a Bruker FT-IR spectrophotometer. ESR spectra of $\mathrm{Cu}$ (II) complexes were carried on a Varian E112X band spectrometer.

This is an open access journal, and articles are distributed under the terms of the Creative Commons Attribution-NonCommercial 4.0 International (CC BY-NC 4.0) License, which allows others to copy and redistribute the material in any medium or format, remix, transform, and build upon the material, as long as appropriate credit is given and the new creations are licensed under the identical terms. 
Synthesis of the Schiff base ligands: The Schiff bases $\left(\mathrm{HL}^{1}\right)$ and $\left(\mathrm{HL}^{2}\right)$ were formed by condensation of 4-methyl3-thiosemicarbazide $(0.012 \mathrm{~g}, 1 \mathrm{mmol})$ with 2,5 -dichlorosalicylaldehyde $(0.019 \mathrm{~g}, 1 \mathrm{mmol})$ and 2,5-dibromosalicylaldehyde $(0.027 \mathrm{~g}, 1 \mathrm{mmol})$ in methanol solution. The reaction mixture was refluxed for $3 \mathrm{~h}$ and the solution was filtered. The yellow precipitate was washed several times with hot methanol and dried under vacuum and all organic impurities were then extracted by washing with diethyl ether. The purity of the ligands was confirmed by thin layer chromatography and the compositions of the ligands were confirmed by elemental analysis and spectroscopic techniques.

Synthesis of metal complexes: The metal complexes were prepared by adding Schiff base ( $\mathrm{HL}^{1} / \mathrm{HL}^{2}, 0.622 / 0.798$, $2 \mathrm{mmol})$ to the appropriate metal salt, $\mathrm{Cu}\left(\mathrm{CH}_{3} \mathrm{COO}\right)_{2} \cdot 3 \mathrm{H}_{2} \mathrm{O}$ $(0.198 \mathrm{~g}, 1.0 \mathrm{mmol}), \mathrm{Ni}\left(\mathrm{CH}_{3} \mathrm{COO}\right)_{2} \cdot 7 \mathrm{H}_{2} \mathrm{O}(0.240 \mathrm{~g}, 1.0 \mathrm{mmol})$ $\mathrm{Co}\left(\mathrm{CH}_{3} \mathrm{COO}\right)_{2} \cdot 4 \mathrm{H}_{2} \mathrm{O}(0.242 \mathrm{~g}, 1.0 \mathrm{mmol})$ and $\mathrm{Zn}\left(\mathrm{CH}_{3} \mathrm{COO}\right)_{2}$. $2 \mathrm{H}_{2} \mathrm{O}(0.201 \mathrm{~g}, 1.0 \mathrm{mmol})$ in $20 \mathrm{~mL}$ aqueous methanol in $2: 1$ molar ratio. The reaction mixture was stirred in and heated on a hotplate at $60{ }^{\circ} \mathrm{C}$ for $100 \mathrm{~min}$. The solid precipitate was obtained and volume of the obtained solution was reduced to one half by evaporation and after this the coloured complexes formed were purified by washing with hot ethanol and diethyl ether and finally dried under vacuum (Scheme-I).

\section{RESULTS AND DISCUSSION}

Condensation of the 2,5-dihalosalicylaldehyde with 4methyl-3-thiosemicarbazide readily gives the Schiff base ligands which were identified by UV, IR, NMR, ESR and mass spectra. Six-coordinate metal complexes were obtained from 2:1 molar ratio of Schiff base ligand with $\mathrm{Cu}\left(\mathrm{CH}_{3} \mathrm{COO}\right)_{2} \cdot 3 \mathrm{H}_{2} \mathrm{O}$, $\mathrm{Ni}\left(\mathrm{CH}_{3} \mathrm{COO}\right)_{2} \cdot 7 \mathrm{H}_{2} \mathrm{O}, \mathrm{Co}\left(\mathrm{CH}_{3} \mathrm{COO}\right)_{2} \cdot 4 \mathrm{H}_{2} \mathrm{O}$ and $\mathrm{Zn}\left(\mathrm{CH}_{3} \mathrm{COO}\right)_{2}$.
$2 \mathrm{H}_{2} \mathrm{O}$. The Schiff-base ligands and their metal complexes are stable at room temperature in solid state and these compounds are generally soluble in DMF and DMSO. The colour, yield, elemental analysis and molar conductance value of all the compounds are presented in Table-1. The analytical data are in agreement with the proposed stoichiometry of the complexes. The metal:ligand ratio in the complexes was found to be 1:2. The molar conductivity values for all the compounds in DMSO was in the range $11-19 \mathrm{ohm}^{-1} \mathrm{~cm}^{2} \mathrm{~mol}^{-1}$, suggesting non-electrolyte nature ligand and complexes (Table-1) [22]. IR, NMR, UV-visible and ESR data indicate the complexes of the formation of tridentate ligands.

IR spectra: The IR spectra of compounds were recorded in the range of $4000-400 \mathrm{~cm}^{-1}$ and band assignments are reported in Table-2. The most characteristic vibrations are selected by comparing the IR spectra of the ligands with those of their metal complexes. The strong bands at $1595-1585 \mathrm{~cm}^{-1}$ for free ligand is due to the azomethine vibration mode, $v(\mathrm{C}=\mathrm{N})$ which gets shifted to the higher frequency in the range of $1630-1608 \mathrm{~cm}^{-1}$ on complexation to metal atom. Ligands display band at $3250-3238 \mathrm{~cm}^{-1}$ which are assigned to $\mathrm{OH}$ vibration modes and this bands gets disappeared after complexation [23]. The sharp and distinct bands present in the far infrared spectra of all complexes at $541-522 \mathrm{~cm}^{-1}$ and 457 $427 \mathrm{~cm}^{-1}, 393-365 \mathrm{~cm}^{-1}$ provide a compelling evidence for the presence of metal-oxygen, metal-nitrogen and metal-sulphur bond, respectively [24].

NMR spectra: ${ }^{1} \mathrm{H}$ NMR spectra of Schiff bases and their complexes were recorded in $\mathrm{CDCl}_{3}$ and DMSO. All chemical shifts were reported in parts per million relative to TMS as internal standard (Table-3). The free ligands showed singlet at $\delta$ 8.03-8.05 ppm due to azomethine proton which gets shifted

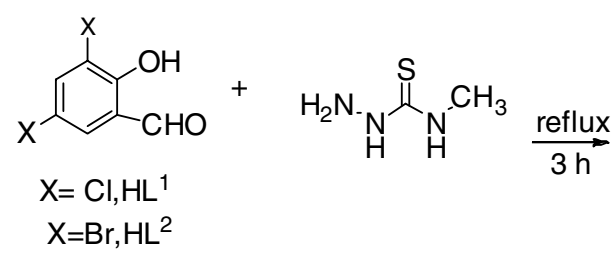

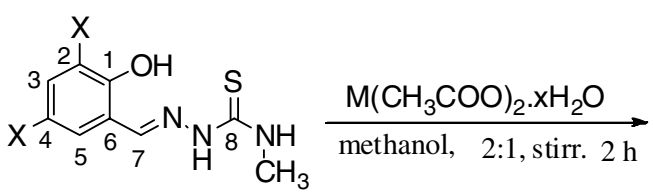

9

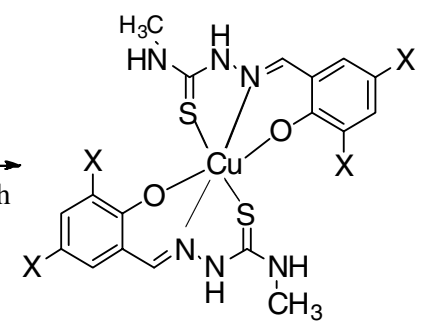

$\mathrm{M}=\mathrm{Co}(\mathrm{II}), \mathrm{Ni}(\mathrm{II}), \mathrm{Cu}(\mathrm{II})$ and $\mathrm{Zn}(\mathrm{II})$

Scheme-I: Synthesis of ligands and their metal complexes

TABLE-1

PHYSICAL AND ANALYTICAL DATA OF COMPOUNDS

\begin{tabular}{|c|c|c|c|c|c|c|c|c|c|}
\hline \multirow{2}{*}{ Compd. } & \multirow{2}{*}{ m.f. } & \multirow{2}{*}{ m.w. } & \multirow{2}{*}{ Colour } & \multirow{2}{*}{$\begin{array}{c}\text { Yield } \\
(\%)\end{array}$} & \multicolumn{4}{|c|}{ Elemental analysis (\%): Calcd. (found) } & \multirow{2}{*}{$\Omega \times 10^{-3}$} \\
\hline & & & & & $\mathrm{C}$ & $\mathrm{H}$ & $\mathrm{N}$ & $\mathrm{M}$ & \\
\hline $\mathrm{HL}^{1}$ & $\mathrm{C}_{9} \mathrm{H}_{9} \mathrm{~N}_{3} \mathrm{OSCl}_{2}$ & 278.16 & Yellow & 75 & $38.86(38.78)$ & $3.26(3.17)$ & $15.11(15.07)$ & - & 13 \\
\hline $\operatorname{Co}\left(\mathrm{L}^{1}\right)_{2}$ & $\mathrm{C}_{18} \mathrm{H}_{16} \mathrm{~N}_{6} \mathrm{O}_{2} \mathrm{~S}_{2} \mathrm{Cl}_{4} \mathrm{Co}$ & 613.33 & Red brown & 73 & $35.25(35.17)$ & $2.63(2.57)$ & $13.70(13.65)$ & $9.61(9.55)$ & 16 \\
\hline $\mathrm{Ni}\left(\mathrm{L}^{1}\right)_{2}$ & $\mathrm{C}_{18} \mathrm{H}_{16} \mathrm{~N}_{6} \mathrm{O}_{2} \mathrm{~S}_{2} \mathrm{Cl}_{4} \mathrm{Ni}$ & 615.15 & Green & 64 & $35.27(35.19)$ & $2.63(2.57)$ & $13.56(13.48)$ & $9.57(9.52)$ & 18 \\
\hline $\mathrm{Cu}\left(\mathrm{L}^{1}\right)_{2}$ & $\mathrm{C}_{18} \mathrm{H}_{16} \mathrm{~N}_{6} \mathrm{O}_{2} \mathrm{~S}_{2} \mathrm{Cl}_{4} \mathrm{Cu}$ & 618.80 & Brown & 78 & $34.99(35.92)$ & $2.61(2.55)$ & $13.60(13.53)$ & $10.29(10.22)$ & 14 \\
\hline $\mathrm{Zn}\left(\mathrm{L}^{1}\right)_{2}$ & $\mathrm{C}_{18} \mathrm{H}_{16} \mathrm{~N}_{6} \mathrm{O}_{2} \mathrm{~S}_{2} \mathrm{Cl}_{4} \mathrm{Zn}$ & 620.34 & White & 76 & $34.89(35.82)$ & $2.60(2.54)$ & $13.56(13.49)$ & $10.55(10.49)$ & 19 \\
\hline $\mathrm{HL}^{2}$ & $\mathrm{C}_{9} \mathrm{H}_{9} \mathrm{~N}_{3} \mathrm{OSBr}_{2}$ & 367.00 & Yellow & 75 & $29.45(29.38)$ & $2.47(4.87)$ & $11.45(4.87)$ & - & 11 \\
\hline $\mathrm{Co}\left(\mathrm{L}^{2}\right)_{2}$ & $\mathrm{C}_{18} \mathrm{H}_{16} \mathrm{~N}_{6} \mathrm{O}_{2} \mathrm{~S}_{2} \mathrm{Br}_{4} \mathrm{Co}$ & 791.33 & Red brown & 73 & $27.33(27.21)$ & $2.04(2.01)$ & $10.62(10.55)$ & $7.45(7.38)$ & 15 \\
\hline $\mathrm{Ni}\left(\mathrm{L}^{2}\right)_{2}$ & $\mathrm{C}_{18} \mathrm{H}_{16} \mathrm{~N}_{6} \mathrm{O}_{2} \mathrm{~S}_{2} \mathrm{Br}_{4} \mathrm{Ni}$ & 793.15 & Green & 64 & $27.33(27.23)$ & $2.04(1.97)$ & $10.62(10.54)$ & $7.42(7.35)$ & 12 \\
\hline $\mathrm{Cu}\left(\mathrm{L}^{2}\right)_{2}$ & $\mathrm{C}_{18} \mathrm{H}_{16} \mathrm{~N}_{6} \mathrm{O}_{2} \mathrm{~S}_{2} \mathrm{Br}_{4} \mathrm{Cu}$ & 795.00 & Brown & 78 & $27.17(27.11)$ & $2.03(1.96)$ & $10.56(10.51)$ & 7.99 (7.92) & 14 \\
\hline $\mathrm{Zn}\left(\mathrm{L}^{2}\right)_{2}$ & $\mathrm{C}_{18} \mathrm{H}_{16} \mathrm{~N}_{6} \mathrm{O}_{2} \mathrm{~S}_{2} \mathrm{Br}_{4} \mathrm{Zn}$ & 796.34 & White & 76 & $27.11(27.07)$ & $2.02(1.95)$ & $10.54(10.49)$ & $8.20(8.13)$ & 17 \\
\hline
\end{tabular}

$\Omega \times 10^{-3}=$ molar conductivity $\left(\mathrm{Ohm}^{-1} \mathrm{~cm}^{2} \mathrm{~mol}^{-1}\right)$ 


\begin{tabular}{|c|c|c|c|c|c|c|c|}
\hline \multicolumn{8}{|c|}{$\begin{array}{c}\text { TABLE-2 } \\
\text { IR SPECTRAL DATA }\left(\mathrm{cm}^{-1}\right) \text { OF LIGANDS AND THEIR METAL COMPLEXES }\end{array}$} \\
\hline Compound & $v(-\mathrm{OH})$ & $v(-\mathrm{C}=\mathrm{N})$ & $v(-\mathrm{C}=\mathrm{S})$ & $v(-\mathrm{NH})$ & $v(\mathrm{M}-\mathrm{N})$ & $v(\mathrm{M}-\mathrm{O})$ & $v(\mathrm{M}-\mathrm{S})$ \\
\hline $\mathrm{HL}^{1}$ & 3250 & 1585 & 805 & 3220 & - & - & - \\
\hline $\mathrm{Co}\left(\mathrm{L}^{1}\right)_{2}$ & - & 1630 & 845 & 3265 & 457 & 541 & 393 \\
\hline $\mathrm{Ni}\left(\mathrm{L}^{1}\right)_{2}$ & - & 1608 & 827 & 3275 & 431 & 525 & 375 \\
\hline $\mathrm{Cu}\left(\mathrm{L}^{1}\right)_{2}$ & - & 1618 & 823 & 3271 & 429 & 527 & 371 \\
\hline $\mathrm{Zn}\left(\mathrm{L}^{1}\right)_{2}$ & - & 1616 & 838 & 3258 & 441 & 535 & 365 \\
\hline $\mathrm{HL}^{2}$ & 3238 & 1595 & 810 & 3260 & - & - & - \\
\hline $\mathrm{Co}\left(\mathrm{L}^{2}\right)_{2}$ & - & 1640 & 848 & 3323 & 452 & 538 & 397 \\
\hline $\mathrm{Ni}\left(\mathrm{L}^{2}\right)_{2}$ & - & 1618 & 831 & 3338 & 437 & 522 & 383 \\
\hline $\mathrm{Cu}\left(\mathrm{L}^{2}\right)_{2}$ & - & 1627 & 828 & 3319 & 427 & 525 & 375 \\
\hline $\mathrm{Zn}\left(\mathrm{L}^{2}\right)_{2}$ & - & 1625 & 841 & 3327 & 439 & 531 & 370 \\
\hline
\end{tabular}

TABLE-3

${ }^{1} \mathrm{H}$ NMR AND ${ }^{13} \mathrm{C}$ NMR SPECTRAL CHARACTERISTICS $(\delta, \mathrm{ppm})$ OF SCHIFF BASES AND ITS ZINC METAL COMPLEXES

\begin{tabular}{|c|c|c|c|c|}
\hline${ }^{1} \mathrm{H}$ NMR & $(\mathrm{O}-\mathrm{H}),(\mathrm{N}-\mathrm{NH}),(\mathrm{R}-\mathrm{NH})$ & $-\mathrm{CH}=\mathrm{N}-$ (azomethine) & Aromatic & $-\mathrm{CH}_{3^{-}}$ \\
\hline $\mathrm{HL}^{1}$ & $\begin{array}{l}9.87(\mathrm{~s}, 1 \mathrm{H},-\mathrm{OH}), 9.12(\mathrm{~s}, 1 \mathrm{H}, \\
-\mathrm{N}-\mathrm{NH}) 6.95(\mathrm{~s}, 1 \mathrm{H}, \mathrm{R}-\mathrm{NH})\end{array}$ & $8.03(\mathrm{~s}, 1 \mathrm{H},-\mathrm{CH}=\mathrm{N}-)$ & $7.43\left(\mathrm{~d}, 1 \mathrm{H}, \mathrm{C}_{3}, \mathrm{Ar}-\mathrm{H}\right), 7.34\left(\mathrm{~d}, 1 \mathrm{H}, \mathrm{C}_{5}, \mathrm{Ar}-\mathrm{H}\right)$ & $3.30(\mathrm{~d}, 3 \mathrm{H})$ \\
\hline $\mathrm{HL}^{2}$ & $\begin{array}{l}9.89(\mathrm{~s}, 1 \mathrm{H},-\mathrm{OH}), 9.15(\mathrm{~s}, 1 \mathrm{H} \\
-\mathrm{N}-\mathrm{NH}) 6.97(\mathrm{~s}, 1 \mathrm{H} \mathrm{R}-\mathrm{NH}) \\
\end{array}$ & $8.05(\mathrm{~s}, 1 \mathrm{H},-\mathrm{CH}=\mathrm{N}-)$ & $7.45\left(\mathrm{~d}, 1 \mathrm{H}, \mathrm{C}_{3} \mathrm{Ar}-\mathrm{H}\right), 7.36\left(\mathrm{~d}, 1 \mathrm{H}, \mathrm{C}_{5}, \mathrm{Ar}-\mathrm{H}\right)$ & $3.32(\mathrm{~d}, 3 \mathrm{H})$ \\
\hline $\mathrm{Zn}\left(\mathrm{L}^{1}\right)_{2}$ & $\begin{array}{l}8.31(\mathrm{~s}, 1 \mathrm{H},-\mathrm{N}-\mathrm{NH}), 6.72(\mathrm{~s}, \\
1 \mathrm{H} \mathrm{R}-\mathrm{NH})\end{array}$ & $8.29(\mathrm{~s}, 1 \mathrm{H},-\mathrm{CH}=\mathrm{N}-)$ & $7.27\left(\mathrm{~d}, 1 \mathrm{H}, \mathrm{C}_{3}, \mathrm{Ar}-\mathrm{H}\right), 7.20\left(\mathrm{~d}, 1 \mathrm{H}, \mathrm{C}_{5}, \mathrm{Ar}-\mathrm{H}\right)$ & $2.75(\mathrm{~d}, 3 \mathrm{H})$ \\
\hline $\mathrm{Zn}\left(\mathrm{L}^{2}\right)_{2}$ & $\begin{array}{l}8.33(\mathrm{~s}, 1 \mathrm{H}, \mathrm{N}-\mathrm{NH}), 6.74(\mathrm{~s}, \\
1 \mathrm{H}-\mathrm{NH})\end{array}$ & $8.31(\mathrm{~s}, 1 \mathrm{H}, \mathrm{CH}=\mathrm{N}-)$ & $7.28\left(\mathrm{~d}, 1 \mathrm{H}, \mathrm{C}_{3} \mathrm{Ar}-\mathrm{H}\right), 7.21\left(\mathrm{~d}, 1 \mathrm{H}, \mathrm{C}_{5}, \mathrm{Ar}-\mathrm{H}\right)$ & $2.78(\mathrm{~d}, 3 \mathrm{H})$ \\
\hline${ }^{13} \mathrm{C}$ NMR & $(\mathrm{C}=\mathrm{S})$ & $-\mathrm{CH}=\mathrm{N}-$ (azomethine) & Aromatic & $-\mathrm{CH}_{3}-$ (methyl) \\
\hline $\mathrm{HL}^{1}$ & 178.02 & 152.58 & $\begin{array}{l}138.58\left(-\mathrm{C}-\mathrm{OH}, \mathrm{C}_{1}\right), 135.40\left(-\mathrm{CH}-, \mathrm{C}_{3}\right), 129.17 \\
\left(-\mathrm{CH}-, \mathrm{C}_{5}\right), 125.62\left(\mathrm{C}_{6}\right), 113.42\left(\mathrm{CBr}, \mathrm{C}_{4}\right), 112.08 \\
\left(-\mathrm{C}-\mathrm{Br}, \mathrm{C}_{2}\right)\end{array}$ & 30.38 \\
\hline $\mathrm{HL}^{2}$ & 178.07 & 155.43 & $\begin{array}{l}138.22\left(-\mathrm{C}-\mathrm{OH}, \mathrm{C}_{1}\right), 135.42\left(-\mathrm{CH}-, \mathrm{C}_{3}\right), 129.19 \\
\left(-\mathrm{CH}-, \mathrm{C}_{5}\right), 125.14,\left(-\mathrm{C}-, \mathrm{C}_{6}\right), 113.42\left(-\mathrm{C}-\mathrm{Br}, \mathrm{C}_{4}\right), \\
112.08\left(-\mathrm{C}-\mathrm{Br}, \mathrm{C}_{2}\right)\end{array}$ & 30.33 \\
\hline $\mathrm{Zn}\left(\mathrm{L}^{1}\right)_{2}$ & 178.42 & 152.21 & $\begin{array}{l}138.22\left(-\mathrm{C}-\mathrm{OH}, \mathrm{C}_{1}\right), 135.42\left(-\mathrm{CH}-, \mathrm{C}_{3}\right), 129.19 \\
\left(-\mathrm{CH}, \mathrm{C}_{5}\right), 125.14\left(-\mathrm{C}-, \mathrm{C}_{6}\right), 113.82\left(-\mathrm{C}-, \mathrm{Br}, \mathrm{C}_{4}\right), \\
112.08\left(-\mathrm{C}-\mathrm{Br}, \mathrm{C}_{2}\right)\end{array}$ & 30.98 \\
\hline $\mathrm{Zn}\left(\mathrm{L}^{2}\right)_{2}$ & 178.53 & 155.32 & $\begin{array}{l}138.22\left(-\mathrm{C}-\mathrm{OH}, \mathrm{C}_{1}\right), 135.42\left(\mathrm{CH}, \mathrm{C}_{3}\right), 129.19(-\mathrm{CH}- \\
\left.\mathrm{C}_{5}\right), 125.14\left(-\mathrm{C}-, \mathrm{C}_{6}\right), 113.42\left(-\mathrm{C}-\mathrm{Br}, \mathrm{C}_{4}\right), 112.38 \\
\left(-\mathrm{C}-\mathrm{Br}, \mathrm{C}_{2}\right)\end{array}$ & 30.87 \\
\hline
\end{tabular}

on complexexation to metal atom (Fig. 1). The phenolic-OH proton showed singlet at $\delta 9.87-9.89$ ppm which gets disappeared in the spectra of zinc complexes suggested coordination of phenolic-OH group to metal ion (Fig. 2). The (N-NH) proton appeared at $\delta$ 9.15-9.12 ppm and $\delta$ 6.97-6.95 ppm (-NH-R) which also gets shifted when complexes are formed. The aromatic proton appeared in range of $\delta 7.45-7.34 \mathrm{ppm}$ which also gets shifted suggested coordination.

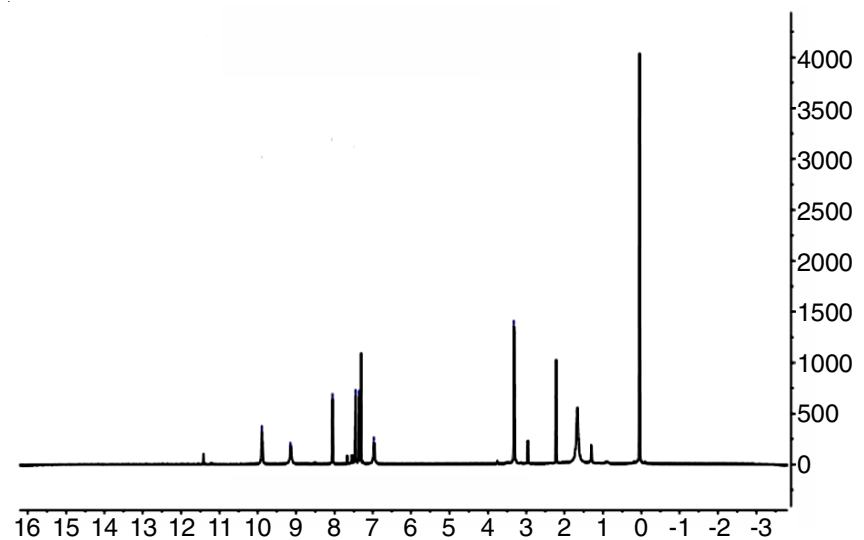

Fig. 1. ${ }^{1} \mathrm{H}$ NMR spectra of Schiff base ligand $\left(\mathrm{HL}^{2}\right)$

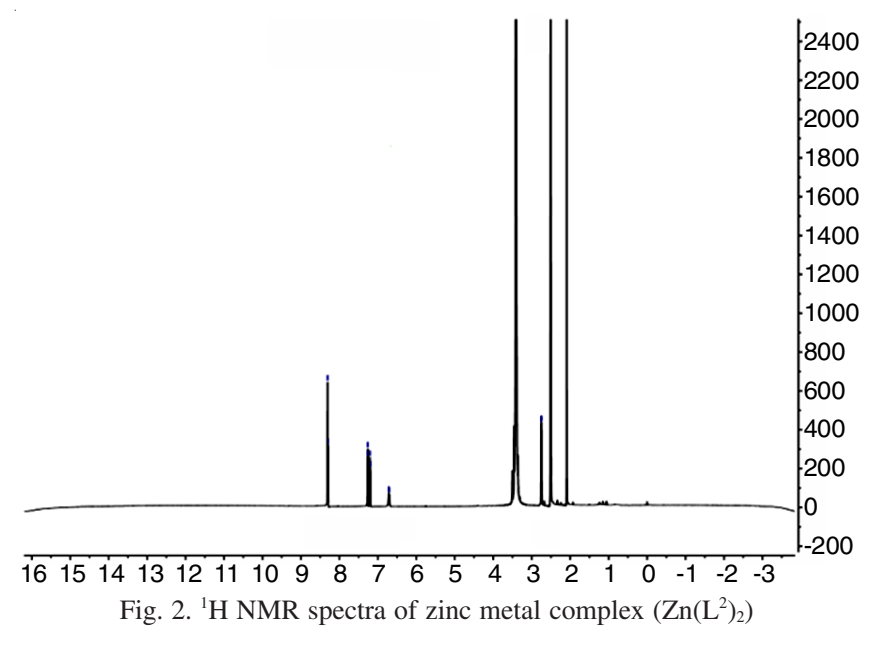

In ${ }^{13} \mathrm{C}$ NMR of $\mathrm{Zn}$ complexes shifting of signals of azomethine carbon $(-\mathrm{CH}=\mathrm{N}-)$ of Schiff base ligands from $\delta 152.58$ to $152.51 \mathrm{ppm}\left(\mathrm{HL}^{1}\right)$ and $\delta 155.43$ to $\delta 155.32 \mathrm{ppm}\left(\mathrm{HL}^{2}\right)$, signal of carbon attached to thiocarbonyl group shift from $\delta$ 178.07-178.02 ppm to $\delta 178.53-178.42 \mathrm{ppm}$. When coordinated to $\mathrm{Zn}$ (II) ions the other carbon atoms were observed in the range of $\delta$ 138.58-112.08 and remains almost unaltered on complexation. 
Electronic spectra: The electronic spectra of the complexes were recorded in DMSO solution (Table-4). Electronic spectra of Co(II) complexes are characterized by three bands in the regions $25431-25483 \mathrm{~cm}^{-1}, 17645-17704 \mathrm{~cm}^{-1}$, 9345$9412 \mathrm{~cm}^{-1}$ and these spectral bands are due to ${ }^{4} \mathrm{~T}_{\mathrm{lg}} \rightarrow{ }^{4} \mathrm{~T}_{\mathrm{lg}}(\mathrm{P})$ ${ }^{4} \mathrm{~T}_{1 \mathrm{~g}} \rightarrow{ }^{4} \mathrm{~T}_{2 \mathrm{~g}}(\mathrm{~F}),{ }^{4} \mathrm{~T}_{1 \mathrm{~g}} \rightarrow{ }^{4} \mathrm{~A}_{2 \mathrm{~g}}(\mathrm{~F})$ transitions. Electronic spectra of $\mathrm{Ni}$ (II) complexes shows three electronic spectral bands in the range of 28245-28263 $\mathrm{cm}^{-1}, 19432-19535 \mathrm{~cm}^{-1}$ and $11567-$ $11627 \mathrm{~cm}^{-1}$. These bands are due to ${ }^{3} \mathrm{~A}_{2 \mathrm{~g}}(\mathrm{~F}) \rightarrow{ }^{3} \mathrm{~T}_{1 \mathrm{~g}}(\mathrm{P})\left(v_{1}\right)$, ${ }^{3} \mathrm{~A}_{2 g}(\mathrm{~F}) \rightarrow{ }^{3} \mathrm{~T}_{1 \mathrm{~g}}(\mathrm{~F})\left(\mathrm{V}_{2}\right),{ }^{3} \mathrm{~A}_{2 \mathrm{~g}}(\mathrm{~F}) \rightarrow{ }^{3} \mathrm{~T}_{2 \mathrm{~g}}(\mathrm{~F})\left(\mathrm{V}_{3}\right)$ transitions, respectively. The position of bands indicates that these complexes have octahedral geometry. In copper complexes one band at $11653-11697 \mathrm{~cm}^{-1}$ is due to $d-d$ transitions and the spectrum also displayed a broad band in the range $22823-22908 \mathrm{~cm}^{-1}$. This band corresponded to the transition ${ }^{2} \mathrm{~B}_{1 \mathrm{~g}} \rightarrow 2 \mathrm{~A}_{1 \mathrm{~g}}$ ). The electronic spectra of the zinc(II) complexes showed one highintensity band at $38453-38496 \mathrm{~cm}^{-1}$ is due to LMCT transition and a band at $28830-28867 \mathrm{~cm}^{-1}$ is due to $\pi \rightarrow \pi^{*}$ transitions. So from the magnetic moment value in Table-4, electronic transitions show that all the complexes are octahedral in nature.

Molar conductivities: Conductivity measurement in nonaqueous solutions is used for testing the degree of ionization of the complexes. The conductivity data reported for $10^{-3} \mathrm{M}$ solution for these complexes are given in Table-1. The conductivity data shows that the complexes are non-electrolytes.

ESR spectra: The X-band EPR spectrum of the $\mathrm{Cu}$ (II) complexes were recorded in the solid state at room temperature. The ESR spectral studies of $\mathrm{Cu}$ (II) complexes gives information about the distribution of unpaired electron and nature of bonding between the metal ion and its ligands. In the present study, ESR spectra of $\left[\mathrm{Cu}\left(\mathrm{L}^{1}\right)_{2}\right]$ had values $\mathrm{g}_{\|}=2.83 ; \mathrm{g}_{\perp}=$ 2.43 and $\left[\mathrm{Cu}\left(\mathrm{L}^{2}\right)_{2}\right]$ (Fig. 3) had values $\mathrm{g}_{\|}=2.69 ; \mathrm{g}=2.33$ and the trend $g_{\|}>g_{\perp}$ observed indicated that the unpaired electrons are most likely to be in $\mathrm{d}_{x^{2}-y^{2}}$ orbital. For complex, the observed $\mathrm{g}$ values are $\mathrm{g}_{\| 1}>\mathrm{g}_{\perp}>2.0023$ which shows that the complexes has an octahedral geometry and the ground state is ${ }^{2} \mathrm{~B}_{1 \mathrm{~g}}$. In the axial spectra, the g-values are related with the exchange interaction coupling constant $\mathrm{G}$ by the expression

$$
\mathrm{G}=\mathrm{g}_{\| 1}-2: 0023 / \mathrm{g}_{\perp}-2: 0023
$$

According to Hathaway and Underhill [25] if G value is larger than four, the exchange interaction is negligible because the local tetragonal axes are aligned parallel or slightly misaligned. In the present $\mathrm{Cu}\left(\mathrm{L}^{1}\right)_{2}$ complex $\mathrm{G}$ value 2.00 and

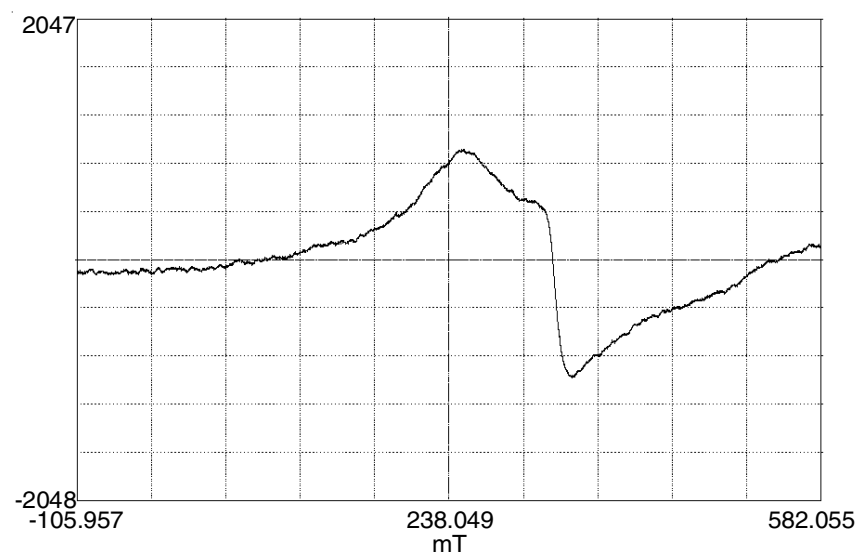

Fig. 3. ESR spectra of $\mathrm{Cu}\left(\mathrm{L}^{1}\right)_{2}$ complex at room temperature

$\mathrm{Cu}\left(\mathrm{L}^{2}\right)_{2}$ complex $\mathrm{G}$ value is 2.0057 , which shows exchange interaction in solid $\mathrm{Cu}(\mathrm{II})$ complexes.

Mass spectra: The mass spectra of Schiff base and their complexes were recorded and are reported in Table-1. The mass spectrum of $\mathrm{HL}^{1}$ shows a well-defined molecular ion peak at $m / z$ 278.16, which matches with a formula weight of Schiff base ligand. Likewise its mass spectrum of $\mathrm{Ni}\left(\mathrm{L}^{1}\right)_{2}$ complex shows a molecular ion peak at $m / z$ 615.12.

\section{Conclusion}

The metal complexes of $\mathrm{Co}(\mathrm{II}), \mathrm{Ni}$ (II), $\mathrm{Cu}$ (II) and $\mathrm{Zn}$ (II) containing tridentate ONS chelating ligands obtained from substituted salicylaldehyde with thiosemicarbazide have been prepared and characterized by elemental analysis, molar conductance, spectroscopic studies (infrared, mass, NMR and ESR. Under experimental conditions employed, only 1:2 (M:L) complexes have been found. Characterization shows that complexes are hexadentate in nature by coordinating in oxygen of phenolic group, nitrogen of azomethine group and sulphur of thiocarbonyl group to metal ions with octahedral geometry.

\section{ACKNOWLEDGEMENTS}

The authors, Manju Yadav and Som Sharma are grateful to DST PURSE and Guru Jambheshwar University of Science and Technology, Hisar, India for financial support.

\section{CONFLICT OF INTEREST}

The authors declare that there is no conflict of interests regarding the publication of this article.

\section{TABLE-4}

ELECTRONIC ABSORPTION SPECTRAL DATA AND MAGNETIC MOMENT OF COMPLEXES

\begin{tabular}{|c|c|c|c|c|}
\hline Ligand/Complex & Absorption $\left(\mathrm{cm}^{-1}\right)$ & Band assignment & $\mu_{\mathrm{eff}}(\mathrm{BM})\left(\mathrm{HL}^{1}, \mathrm{HL}^{2}\right)$ & Geometry \\
\hline$\left[\mathrm{HL}^{1}, \mathrm{HL}^{2}\right]$ & $\begin{array}{l}30845,31645 \\
29347,29735 \\
\end{array}$ & $\begin{array}{l}\pi \rightarrow \pi^{*} \text { transitions } \\
\mathrm{n} \rightarrow \pi^{*} \text { transitions }\end{array}$ & - & - \\
\hline $\mathrm{Co}\left(\mathrm{L}^{1}\right)_{2 .} \mathrm{Co}\left(\mathrm{L}^{2}\right)_{2}$ & $\begin{array}{c}25431,35483 \\
17645,17704 \\
9345,9415\end{array}$ & $\begin{array}{c}\pi \rightarrow \pi^{*} \text { transitions } \\
\mathrm{n} \rightarrow \pi^{*} \text { transitions } \\
d-d \text { transitions }\end{array}$ & $5.18,5.88$ & Octahedral \\
\hline $\mathrm{Ni}\left(\mathrm{L}^{1}\right)_{2}, \mathrm{Ni}\left(\mathrm{L}^{2}\right)_{2}$ & $\begin{array}{l}28245,28283 \\
19432,19539 \\
11567,11627\end{array}$ & $\begin{array}{c}\pi \rightarrow \pi^{*} \text { transitions } \\
\mathrm{n} \rightarrow \pi^{*} \text { transitions } \\
d-d \text { transitions }\end{array}$ & $3.73,3.87$ & Octahedral \\
\hline $\mathrm{Cu}\left(\mathrm{L}^{1}\right)_{2}, \mathrm{Cu}\left(\mathrm{L}^{2}\right)_{2}$ & $\begin{array}{l}22823,22908 \\
11653,11793\end{array}$ & $\begin{array}{c}\mathrm{n} \rightarrow \pi^{*} \text { transitions } \\
d-d \text { transitions }\end{array}$ & $1.79,1.83$ & Octahedral \\
\hline $\mathrm{Zn}\left(\mathrm{L}^{1}\right)_{2}, \mathrm{Zn}\left(\mathrm{L}^{2}\right)_{2}$ & $\begin{array}{l}28830,28867 \\
38456,38496\end{array}$ & $\begin{array}{c}\pi \rightarrow \pi^{*} \text { transitions } \\
\text { LMCT }\end{array}$ & Diamagnetic & Octahedral \\
\hline
\end{tabular}




\section{REFERENCES}

1. A.H. Osman, Transition Met. Chem., 31, 35 (2006); https://doi.org/10.1007/s11243-005-6265-7.

2. J. Devi, S. Devi and A. Kumar, MedChemComm, 7, 932 (2016); https://doi.org/10.1039/C5MD00554J.

3. C. Sousa, C. Freire and B. de Castro, Molecules, 8, 894 (2003); https://doi.org/10.3390/81200894.

4. J. Costamagna, J. Vargas, R. Latorre, A. Alvarado and G. Mena, Coord. Chem. Rev., 119, 67 (1992);

https://doi.org/10.1016/0010-8545(92)80030-U.

5. M. Cindric, N. Strukan, V. Vrdoljak, T. Kajfez and B. Kamenar, Croat. Chem. Acta, 76, 157 (1992).

6. D.E. Hamilton, R.S. Drago and A. Zombeck, J. Am. Chem. Soc., 109, 374 (1987); https://doi.org/10.1021/ja00236a014.

7. J.M. Bindlish, S.C. Bhatia, P. Gautam and P.C. Jain, Indian J. Chem., 16A, 279 (1978).

8. R.A. Ahmadi and S. Amani, Molecules, 17, 6434 (2012); https://doi.org/10.3390/molecules17066434.

9. P. Jain and K.K. Chaturvedi, J. Inorg. Nucl. Chem., 39, 901 (1993); https://doi.org/10.1016/0022-1902(77)80182-6.

10. R.D. Archer and B. Wang, Inorg. Chem., 29, 39 (1990); https://doi.org/10.1021/ic00326a009.

11. R.-G. Xiong, B.-L. Song, J.-L. Zuo, X.-Z. You and X.-Y. Huang, Polyhedron, 15, 903 (1996); https://doi.org/10.1016/0277-5387(95)00319-6.

12. T.S. Lobana, R. Sharma, G. Bawa and S. Khanna, Coord. Chem. Rev., 253, 977 (2009); https://doi.org/10.1016/j.ccr.2008.07.004.
13. J.R. Dilworth and R. Hueting, Inorg. Chim. Acta, 389, 3 (2012); https://doi.org/10.1016/j.ica.2012.02.019.

14. V. Philip, V. Suni, M.R.P. Kurup and M. Nethaji, Polyhedron, 25, 1931 (2006); https://doi.org/10.1016/j.poly.2005.12.023.

15. F.A. French and E.J. Blanz Jr., J. Med. Chem., 9, 585 (1966); https://doi.org/10.1021/jm00322a032.

16. M. Das and S.E. Livingstone, Br. J. Cancer, 37, 466 (1978); https://doi.org/10.1038/bjc.1978.68.

17. A.S. Dobek, D.L. Klayman, E.T. Dickson, J.P. Scovill and E.C. Tramont, Antimicrob. Agents Chemother, 18, 27 (1980); https://doi.org/10.1128/AAC.18.1.27.

18. C. Shipman Jr., J.R. Smith, J.C. Drach and D.L. Klayman, Antiviral Res., 6, 197 (1986); https://doi.org/10.1016/0166-3542(86)90002-1.

19. M. Kabil, S. Ghazy, A. El-Asmy and Y. Sherif, Anal. Sci., 12, 431 (1996); https://doi.org/10.2116/analsci.12.431.

20. G.A. Al-Hazmi, M.S. El-Shahawi and A.A. El-Asmy, Transition Met. Chem., 30, 464 (2005); https://doi.org/10.1007/s11243-005-2362-x.

21. K.S. Kuamr and C.P. Varma, J. Pharm. Sci. Res., 9, 131 (2017).

22. J. Devi, N. Batra, S. Sharma, J. Yadav and R. Malhotra, Der. Pharm. Chem., 9, 97 (2017).

23. J. Devi and N. Batra, Spectrochim. Acta A Mol. Biomol. Spectrosc., 135, 710 (2015); https://doi.org/10.1016/j.saa.2014.07.041.

24. M.M. Abd-Elzaher, Appl. Organomet. Chem., 18, 149 (2004); https://doi.org/10.1002/aoc.608.

25. B.J. Hathaway and A.E. Underhill, J. Chem. Soc., 3091 (1961); https://doi.org/10.1039/JR9610003091. 